\title{
Government Subsidies and Enterprise Innovation: Evidence from China's Photovoltaic Industry
}

\author{
Cailou Jiang $\mathbb{D}^{1},{ }^{1}$ Dehai Liu $\mathbb{D}^{1},{ }^{1}$ Qin Zhu $\mathbb{D}^{\mathbb{D}},{ }^{2}$ and Lu Wang ${ }^{3}{ }^{3}$ \\ ${ }^{1}$ Development Institute of Jiangbei New Area, Nanjing University of Information Science \& Technology, Nanjing 210044, China \\ ${ }^{2}$ Institute for the History of Science and Technology, Nanjing University of Information Science \&Technology, \\ Nanjing 210044, China \\ ${ }^{3}$ Faculty of Business, Economics \& Law, The University of Queensland, Brisbane, Queensland 4072, Australia \\ Correspondence should be addressed to Qin Zhu; 002165@nuist.edu.cn
}

Received 7 February 2021; Revised 3 May 2021; Accepted 12 June 2021; Published 22 June 2021

Academic Editor: Benjamin Miranda Tabak

Copyright (c) 2021 Cailou Jiang et al. This is an open access article distributed under the Creative Commons Attribution License, which permits unrestricted use, distribution, and reproduction in any medium, provided the original work is properly cited.

\begin{abstract}
Government subsidies (GSs) have triggered a remarkable increase in the production capacity of photovoltaic (PV) electricity in China. However, the lack of core technologies has limited PV enterprises' competitiveness in the global market. This research investigates the impacts of $R \& D$ subsidies and non-R\&D subsidies on the innovation in PV enterprises. With samples of Chinese listed PV enterprises from 2010 to 2019, this study finds R\&D subsidies exert a notable positive impact on the innovation in PV enterprises. In small and medium enterprises (SMEs) and enterprises without state-owned shares, both R\&D subsidies and nonR\&D subsidies have positive impacts on the innovation. Considering the policy orientation, R\&D subsidies granted under demand-orientation policies promote the innovation in PV enterprises. The government should increase the amount of R\&D subsidies, optimize the R\&D subsidies' evaluation mechanism, and reasonably grant R\&D subsidies from the demand side.
\end{abstract}

\section{Introduction}

1.1. Background. With the intensification of energy shortage and environmental pollution, renewable energy has attracted worldwide attention [1-4]. The solar photovoltaic $(\mathrm{PV})$ power is abundant, clean, and convenient and also has been considered as one of the most promising renewable energies $[5,6]$. Due to the ever-increasing energy and environmental pressures, China is switching to focus more on fostering the PV industry. The primary policy instrument to start PV industry in China is government subsidy (hereinafter GS), which was granted to PV enterprises to incentivize the investment in the PV system and supporting facilities. Under the "Golden Solar Demonstration Project in China," the GSs were granted to PV enterprises based on the total amount of investment between 2009 and 2013. To stimulate the generation of PV electricity, GSs were granted to PV enterprises through feed-in tariffs (FITs) (Feed-in tariff (FIT) is a policy instrument that guarantees the purchase of PV power at fixed prices) or based on the kilowatt hours of generated power after 2013. According to the data released by the National Energy Administration [7], the newly added generation capacity of PV electricity in China in 2017 reached 53.06 billion-watt, and the production of silicon slice reached 87 billion-watt. In terms of generation capacity, China has ranked first in the world.

PV technologies are critical to the sustainable development of PV enterprises. China's photovoltaic industry has formed an industrial chain system with silicon-wafer and solar-cell production in the upper-middle streams and photovoltaic application installation in the downstream. However, the important high-purity polycrystalline silicon and thin-film solar cells materials in the upper-middle streams are mainly imported from the United States, Germany, Russia, and other countries, and there is still a gap with the advanced world level in some core technologies such as solar power systems and power generation detections in the downstream. Since the environmental benefits and knowledge creation cannot be fully redeemed by the market, technological innovation in PV enterprises will 
encounter the "double externality problem" [8, 9]. As a result, PV enterprises will underinvest in $\mathrm{R} \& \mathrm{D}$ activities, which make GSs necessary to fill the investment gap $[8,10]$. Due to the government's strong desire in developing strategic emerging industries in China, generous subsidies have been granted to PV enterprises and have triggered a marked increase in PV electricity production. Nonetheless, substantial subsidies may also induce PV enterprises to expand production to benefit from economies of scale and shift resources from risky $\mathrm{R} \& \mathrm{D}$ activities towards exploiting existing mature technologies. In the long run, it may lead to technological lock-ins and hinder the diffusion of more advanced technologies [11].

GSs have been employed to reduce costs and create demand for technological innovation in PV industry in developed countries [12]. With generous GSs, China leads regarding the scale of $\mathrm{PV}$ power generation. However, whether these subsidies have fostered innovation in PV technology is becoming a controversial issue. Until now, most previous studies of PV enterprises innovation are conducted on cross-country or cross-industry samples, which cannot exclude the heterogeneity of different countries or industries. In China, few studies have been conducted to analyze the panel data of PV enterprises under the policy of GS, especially R\&D subsidies and non-R\&D subsidies. This research tries to fill this gap by scrutinizing the impact of R\&D subsidies on the innovation in PV enterprises by applying the data of 70 Chinese listed enterprises from 2010 to 2019. The heterogeneity, including enterprises' scale, ownership structure, and the policy orientations are also analyzed.

1.2. Literature Review and Research Hypothesis. Many research studies have focused on the diffusion of PV electricity. With an improved finite element model, Karakaya [13] forecasted the diffusion of PV power generation system in southern Germany. Bhattarai et al. [14] find that the subsidy program for Solar Home System in Nepal is successful at reaching the poor families. Nomaguchi et al. [15] find that the subsidy on distributed generation device installation in Japan has accelerated the diffusion of PV electricity. In the U.S., the Property Assessed Clean Energy program has promoted the residential PV installation in the northern California [16], and the PV electricity will be competitive when the generation cost is similar to the retail electricity rate [17]. However, higher installation costs will depress the diffusion of PV electricity [18], and a high rate of technological change may delay the diffusion of PV electricity if the consumers have a rational price expectation [19]. When the households have no sufficient awareness about the PV system, the enhancement of communication and social networking services may also delay the diffusion of PV electricity [20].

Moreover, some research studies have investigated the economic performance of GSs in PV industry. Xiong and Yang [6] find that GSs have improved the sales revenue and net profit of PV enterprises in China. Chou et al. (2015) find that GSs in China have reduced the cost of PV electricity and accelerated the prosperity of PV industry [21]. By estimating the cost trend of PV cells, Zhang et al. [22] found that longterm subsidies in China for PV electricity are feasible. However, $\mathrm{Xu}$ et al. [23] find that excessive government intervention is not conducive to the development of the PV industry, and long-term government subsidies have little impact on PV enterprises' performance. Considering the practical conditions, distributed PV projects are economically unfeasible under existing subsidy policies [24]. In Austria, subsidies for PV industry lead to a potential increase of the cumulative production of electricity [25], and subsidies in the U.S. transferred from nuclear to PV industry result in more electricity throughout the technology life cycle [26].

Besides, several research studies also probed the influences of GSs on enterprises' innovation in the renewable energy field. Olson [27] finds that GS in the U.S. has not created effective incentives for renewable energy technology innovation, while Koseoglu et al. [28] find that California's support policy is effective in reducing the initiating costs of renewable energy technologies. With a global sample, Hoppmann et al. [9] find that aggressive subsidies on the demand side have promoted enterprises' $R \& D$ investments in PV technology exploration. Nicolli and Vona [29] find GSs in 19 EU countries have spurred innovation in PV technology from 1980 to 2007 . With patent data of 25 OECD countries over the period of 1978-2003, Johnstone et al. [30] find the positive innovation impact of GSs on solar PV technologies. Tsai [31] finds that the subsidiary and innovative programs starting from 2013 in Taiwan have promoted the innovation of PV technologies.

Meanwhile, some research studies have begun to focus on the effects of $\mathrm{R} \& \mathrm{D}$ subsidies on the enterprises' innovation. Clausen (2009) finds that $R \& D$ subsidies can significantly promote enterprises R\&D spending in Norway. Bronzini and Piselli [32] find that R\&D subsidies program conducted in northern Italy can effectively increase the patent applications by subsidized enterprises. Lucy and David [33] also find that R\&D subsidies can spur innovation in the UK. With a panel data of manufacturing enterprises in China, Gao et al. [34] find that both central and local R\&D subsidies policies are successful in promoting enterprises' exploratory innovation. With a panel data of renewable energy enterprises in China, Wu et al. [35] find that government R\&D subsidies can significantly increase renewable energy investment, and $\mathrm{Li}$ et al. [36] find that it can also stimulate renewable energy innovation at certain intervals.

Theoretically, firstly, enterprises' innovation has the characteristics of high risk and external spillover [37]. It is necessary to introduce a group of high-quality and skilled $\mathrm{R} \& \mathrm{D}$ personnel and advanced equipment in the process of innovation activities. And the achievements of innovation are easy to be imitated, resulting in the phenomenon of "hitchhiking" and thereby reducing the expected income of PV enterprises. GSs, as nonoperating income of PV enterprises, can effectively share the cost of enterprise $R \& D$ investment, reduce the negative impact of external spillover effects of innovation achievements, and strengthen the driving force for PV enterprise innovation [38]. 
Secondly, PV enterprises that receive government subsidies can transmit positive signal effects to the outside investors and broaden the subsequent financing channels. R\&D subsidy, as an important government subsidy policy to support enterprises' innovation, is more stringent in selecting subsidized enterprises and sends a stronger positive signal. Once PV enterprises receive R\&D subsidies from government, it can more effectively reduce the problem of information asymmetry with external investors, ease enterprises' financing constraints, and provide material support for enterprises' innovation [39]. Based on the above analysis, this article proposes the following hypothesis.

Hypothesis 1. R\&D subsidies exert a significant and positive influence on the innovation in PV enterprises.

1.3. Motivations and Contributions. There are three main motivations to scrutinize the impacts of GSs on China's PV enterprises' innovation. First, innovation activities constitute the foundation of exploring new technologies in PV enterprises. Without sufficient innovation efforts, China's PV industry may be developed with high cost and inefficient technologies and can hardly relieve the energy and environmental pressures for the low conversion rates of solar power. Second, GSs may cut down the production cost and compensate for the underinvestment in R\&D activities in PV enterprises. However, excessive subsidies may cause lock-ins in existing mature technologies and hinder the diffusion of more advanced technologies. Finally, the influence of GSs on PV enterprises' innovation is likely to be affected by the ownership, enterprise size, and the policy orientations. Therefore, it is necessary to conduct an in-depth investigation on the impacts of GSs on China's PV enterprises' innovation.

This research sheds light on the impacts of GSs on PV enterprises' innovation in China in the context of catch-up strategy. First, by taking Chinese PV enterprises as an overall sample, this study excludes the heterogeneity of different countries or industries. Second, the ownership structure and the size of PV enterprises may influence the impact of GSs, and thus the heterogeneity of state-owned shareholdings and scale are investigated. Finally, this study distinguishes the impacts of GSs under different policy orientations.

\section{Empirical Framework: Model Specification and Data}

2.1. Model Specification. Enterprise innovation is targeted at exploring new technologies through the utilization of internal resources [40]. With the intensification of market competition and upgradation of technologies, more innovation is needed for Chinese PV enterprises to obtain the competitive advantage in the global market [41]. However, these innovations suffer from environmental externalities and knowledge spillover and further result in underinvestment in PV enterprises' innovation activities [9]. Thus, GSs are critical to complement the underinvestment. In existing literatures, GSs have been found to be effective in promoting enterprises' innovation efforts through decentralizing innovation risks, reducing innovation costs, and providing "signal effects" [32, 42-44]. In this vein, GSs should have a positive influence on PV enterprises' R\&D efforts.

In China, the survival, growth, and innovation of PV enterprises are affected directly by the government support, and GSs are usually granted to PV enterprises for R\&D incentive purpose and non-R\&D purpose. Here, GSs are divided into R\&D subsidies (RDSub) and non-R\&D subsidies (NRDSub).

Apart from GSs, innovations in PV enterprises in China are also influenced by internal factors, such as the scale of enterprise, state ownership, financial condition, age [45-47], and external factors, such as market profit $[48,49]$. To probe the influencing mechanism of GSs on PV enterprises' innovation, a basic econometric model is used as follows:

$$
\begin{aligned}
\text { Inno }_{\text {it }}= & \beta_{0}+\beta_{1} \text { RDSub }_{i t}+\beta_{2} \text { NRDSub }_{\text {it }}+\beta_{3} \text { Own }_{i t}+\beta_{4} \text { Size }_{i t}+\beta_{5} \text { Profit }_{\text {it }} \\
& +\beta_{6} \text { Debt }_{i t}+\beta_{7} \text { Age }_{i t}+\mu,
\end{aligned}
$$

where $i$ denotes PV enterprise and $t$ denotes the time duration from 2010.

2.2. Definition of Main Variables. "Inno" refers to the innovation of PV enterprises. As R\&D intensity captures the commitment and efforts of enterprises to innovation activities [50], we employed R\&D intensity to measure the innovation in PV enterprises. In prior literatures [43, 49], the R\&D intensity was calculated as the ratio of enterprises' R\&D investment to the total sales revenue. Considering the sales revenue of PV enterprises may be inflated by the massive amount of subsidies, this study uses the ratio of
$R \& D$ investment to the fixed capital to measure the $R \& D$ intensity.

Government subsidy is the main fiscal instrument used by the government to support PV enterprises. Since enterprises' innovation activities are capital-intensive, GSs are critical for PV enterprises to complement the underinvestment in innovation activities and thus influence the innovation decisions. Here, GSs are divided into R\&D subsidies and non-R\&D subsidies. Since there is no separate column of R\&D subsidies in the annual report of the enterprise, referring to the literature of [35], RDSub is calculated by filtering all specific items in enterprise government subsidy directory. If the item name contains the 
keywords "research," "patent," “innovation," "talent introduction," "intellectual property," "technical innovation," "industrial upgrading," and so on, then sum the amount of these corresponding items as RDSub. The amount of NRDSub is calculated as the GSs minus the RDSub.

Size refers to the scale of PV enterprise. Large firms may support innovation with large-scale financial support and undertake higher innovation risks and costs than small enterprises [51]. Here, PV enterprises' fixed capital is used to denote the size.

Own refers to the proportion of state-owned shares in a PV enterprise. In China, managers in state-owned PV enterprises may not get rewarded from the innovation efforts, but they have to undertake the risks. Therefore, PV enterprises with higher proportion of state-owned shares may be more reluctant to carry out innovation activities [47].

Profit refers to the market profit. Market profit can create favorable conditions to support innovation activities in PV enterprises [52]. With sufficient innovation efforts, PV enterprises may make technical progress and earn super profits in the market [49].

Debt represents the asset-liability ratio of PV enterprises, which reflects the financial condition of PV enterprises. Generally speaking, a lower debt rate may promote the innovation efforts of PV enterprises with more sufficient floating capital [45].

Age refers to the age of years being a listed PV enterprise. A longer age may lead to higher management efficiency, richer market resources, and better technical capabilities and further influence PV enterprises' innovation efforts [45]. Durations of the PV enterprises becoming listed were calculated to reflect the age.

The definition of main variables is listed in Table 1.

2.3. Samples and Data Sources. 70 listed PV enterprises during the period from 2010 to 2019 are chosen as research samples. The amount of GSs that PV enterprises received from the government and the data of Inno, Size, Profit, Debt, Talent, Own, and Age are accessed from China Stock Market and Accounting Research Database. The data of RDSub are collected in the yearbook of listed PV enterprises. The prices are deflated to the 1978 value to eliminate the influence of inflation (the prices are generally deflated to 1978 when China's economic reform started). The absolute values of variables are taken logarithm to eliminate the multiple collinearity.

\section{Empirical Results}

3.1. Descriptive Statistical Analysis. The descriptive statistics of the variables are provided in Table 2. Table 3 shows the correlation matrix. The correlation coefficients are lower than 0.6. Thus, this research will not be affected significantly by the multiple collinearity.

3.2. Baseline Regression. Because most of the Inno values fall between 0 and 1, a Tobit method is suitable for the test. The empirical results of equation (1) are shown in Table 4.
Individual effect (Firm) and time effect (Year) are controlled in column (3).

According to the regression results, we find the average effects as shown by the coefficients of RDSub are positive significantly, and the coefficients of NRDSub are insignificant. This implies that RDSub exerts a significantly positive impact on the innovation in PV enterprises during the period of 2010 to 2019, and Hypothesis 1 has been verified. This is similar to the results found in Korea and Germany $[12,53]$. A possible explanation is that RDSub in China has created favorable conditions for the innovation in PV enterprises through reducing innovation costs directly and even has encouraged the innovation in PV enterprise for the sake of honor.

3.3. Robustness Testing. The robustness of the results is verified by replacing the test method and the explained variable. In Table 5, innovation is defined as the ratio of PV enterprises' R\&D investment to the total business income (\%) in column (4). Column (5) is the regression results of the OLS method. To alleviate the endogeneity caused by mutual causation, the GS with a lag of 1 period is adopted as an explanatory variable [54] in column (6). The coefficients are consistent with the results in Table 4, which indicate that the results are robust.

3.4. Heterogeneity Analysis. To get further information about the PV enterprises of different scales, the samples are divided into small and medium enterprise (SME) group and large-sized enterprise group. The fixed capital for SME is less than 100 million RMB, and the large-sized enterprises' fixed capital is set as more than 100 million RMB [46]. The results are provided in column (7) and column (8) in Table 6 . We find the coefficients of RDSub and NRDSub are both positive significantly in column (7), and only the coefficient of RDSub is significantly positive in column (8). PV sector is a high-tech industry, and innovation constitutes the basis for enterprises to acquire competitive advantage in the market [55]. To compete with large enterprises in the fast-growing market in China, PV enterprises with smaller scale need to input more R\&D investments to capture the changing technological opportunities and market opportunities $[56,57]$. GSs for R\&D purpose and non-R\&D purposes may alleviate the shortage of funds for innovation and thus promote the R\&D intensity of SMEs.

In China, the state-owned shares may influence enterprises' willingness to input in innovation activities $[45,46]$. In Table 6, the results of PV enterprises without state-owned shares are shown in column (9), and the results of PV enterprises with state-owned shares are shown in column (10). The results indicate that the coefficients of RDSub and NRDSub are both positively significant in column (9), but both are insignificant in column (10). This implies that given a certain amount of GSs, PV enterprises without stateowned shares are more willing to carry out R\&D activities. Because these enterprises are small and short of capital, they can only acquire better profits and competitive advantages in the market through innovation efforts. GSs can fill the gap of 
TABLE 1: Definition of main variables.

\begin{tabular}{lc}
\hline Variables & Definition \\
\hline $\begin{array}{l}\text { Inno } \\
\text { RDSub }\end{array}$ & Ratio of PV enterprises' R\&D investment to the fixed capital (\%) \\
NRDSub & $\begin{array}{c}\text { Logarithm value of GSs that PV enterprises received for R\&D incentive purpose from government (10,000 Yuan) } \\
\text { Lize }\end{array}$ \\
$\begin{array}{l}\text { Profit } \\
\text { Debt }\end{array}$ & $\begin{array}{c}\text { Logarithm value of GSs that PV enterprises received from government minus the amount for R\&D incentive purpose } \\
\text { Own }\end{array}$ \\
Age & Logarithm value of PV enterprises' net profit (10,000 Yuan)
\end{tabular}

Table 2: Descriptive statistics.

\begin{tabular}{lcccc}
\hline Variables & Mean & Standard deviation & Min & Max \\
\hline Inno & 13.243 & 20.210 & 0.006 & 0.000 \\
RDSub & 7.035 & 2.254 & 0.000 & 12.452 \\
NRDSub & 9.515 & 2.742 & 0.000 & 14.174 \\
Size & 13.932 & 2.892 & 0.000 & 17.61 \\
Own & 0.033 & 0.107 & 0.000 & 0.759 \\
Profit & 15.805 & 7.018 & 0.015 & 22.438 \\
Debt & 0.475 & 0.229 & 0.000 & 2.861 \\
Age & 1.941 & 0.898 & 3.332 \\
\hline
\end{tabular}

TABLE 3: Correlation between independent variables.

\begin{tabular}{lcccccrr}
\hline Variables & Inno & RDSub & NRDSub & Size & Own & Profit & Debt \\
\hline Inno & 1.00 & & & & & & \\
RDSub & 0.156 & 1.000 & & & & & \\
NRDSub & 0.044 & 0.526 & 1.000 & & & & \\
Size & -0.537 & 0.003 & 0.104 & 1.000 & & & \\
Own & -0.124 & -0.164 & -0.151 & 0.312 & 1.000 & & \\
Profit & 0.116 & 0.138 & 0.070 & 0.121 & -0.104 & 1.000 & 1.000 \\
Debt & -0.247 & 0.107 & 0.016 & 0.431 & 0.253 & -0.203 & 0.042 \\
Age & -0.383 & 0.048 & 0.036 & 0.588 & 0.198 & -0.083 & 1.000 \\
\hline
\end{tabular}

TABLE 4: Estimates of the effects of government subsidies.

\begin{tabular}{lccc}
\hline & $(1)$ & $(2)$ & $(3)$ \\
\hline RDSub & $1.573^{* * *}(3.19)$ & $1.226^{* * *}(2.99)$ & $1.074^{* * *}(2.64)$ \\
NRDSub & $-0.382(-0.91)$ & $0.246(0.70)$ & $0.343(1.00)$ \\
Size & & $-7.378^{* * *}$ & $-7.891^{* * *}$ \\
& & $(-10.35)$ & $(-11.00)$ \\
Own & & $21.573^{* *}(2.36)$ & $24.049^{* * *}(2.66)$ \\
Profit & & $-0.468^{* * *}(4.15)$ & $0.443^{* * *}(4.00)$ \\
Debt & & $-5.082(1.21)$ & $5.269(1.28)$ \\
Age & & $-1.947^{*}(-1.71)$ & $-3.450^{* * *}(2.93)$ \\
Firm & No & No & Yes \\
Year & No & No & Yes \\
LR Chi ${ }^{2}$ & 10.89 & 179.31 & 195.45 \\
OBS & 409 & 409 & 409 \\
\hline
\end{tabular}

Note: $t$-statistics reported in parentheses. ${ }^{*} p<0.1,{ }^{* *} p<0.05$, and ${ }^{* * *} p<0.01$.

enterprise innovation funds and disperse the risk of enterprise innovation activities and thereby may stimulate the innovation in the PV enterprises without state-owned shares. As for PV enterprises with a higher proportion of state-owned shares, they have an advantage of acquiring
Table 5: Robustness testing.

\begin{tabular}{lccc}
\hline & $(4)$ & $(5)$ & $(6)$ \\
\hline RDSub & $0.239^{* * *}(3.42)$ & $1.074^{* * *}(2.61)$ & \\
RDSub -1 & & & $0.809^{* *}(2.13)$ \\
NRDSub & $0.035(0.59)$ & $0.343(0.98)$ & $0.403(1.18)$ \\
Size & $-0.259^{* *}(-2.12)$ & $-7.891^{* * *}(-10.96)$ & $-7.906^{* * *}(-9.92)$ \\
Own & $-1.459(-0.94)$ & $24.049^{* * *}(2.62)$ & $16.122^{*}(1.79)$ \\
Profit & $-0.043^{* *}(-2.26)$ & $0.424^{* * *}(3.32)$ & $0.424^{* * *}(3.38)$ \\
Debt & $-5.128^{* * *}(-7.13)$ & $5.269(1.26)$ & $10.232^{* *}(2.18)$ \\
Age & $-0.052^{* *}(-0.26)$ & $-3.450^{* * *}(-2.89)$ & $-3.195^{* *}(-2.30)$ \\
Firm & Yes & Yes & Yes \\
Year & Yes & Yes & Yes \\
LR/F & 114.65 & 27.16 & 127.35 \\
OBS & 405 & 409 & 290 \\
\hline
\end{tabular}

$t$-Statistics reported in parentheses. ${ }^{*} p<0.1,{ }^{* *} p<0.05$, and ${ }^{* * *} p<0.01$.

financial support by political background and network under the massive GSs [58]. However, this advantage may also encourage rent-seeking and reduce innovation efforts in these enterprises. Furthermore, managers in PV enterprises with a higher proportion of state-owned shares have few 
TABLE 6: Heterogeneity analysis.

\begin{tabular}{|c|c|c|c|c|c|c|}
\hline & \multicolumn{2}{|c|}{ Enterprise size } & \multicolumn{2}{|c|}{ Enterprise ownership } & \multicolumn{2}{|c|}{ Policy orientation } \\
\hline & $(7)$ & $(8)$ & (9) & $(10)$ & $(11)$ & $(12)$ \\
\hline RDSub & $1.940^{* *}(2.55)$ & $0.655^{* *}(2.03)$ & $1.690^{* * *}(3.55)$ & $0.574(0.83)$ & $1.075(1.43)$ & $1.148^{* *}(2.47)$ \\
\hline NRDSub & $3.795^{* * *}(3.36)$ & $0.182(0.74)$ & $1.422^{* * *}(3.25)$ & $-0.421(-0.72)$ & $1.094(1.66)$ & $0.262(0.67)$ \\
\hline Size & $-27.567^{* * *}(-12.41)$ & $-4.240^{* * *}(-5.81)$ & $-9.780^{* * *}(-11.47)$ & $-4.58^{* * *}(-3.77)$ & $-14.500^{* * *}(-10.34)$ & $-5.550^{* * *}(-7.14)$ \\
\hline Own & $21.283(0.71)$ & $6.221(0.99)$ & & $10.405(1.38)$ & $26.273^{*}(1.83)$ & $10.691(0.97)$ \\
\hline Profit & $0.179(0.85)$ & $0.286^{* * *}(3.20)$ & $-0.474^{* * *}(3.61)$ & $0.088(0.62)$ & $0.545^{* * *}(2.82)$ & $0.361^{* *}(2.82)$ \\
\hline Debt & $-6.194(-0.85)$ & $0.801(0.23)$ & $5.651(1.24)$ & $-10.986(-1.53)$ & $-10.519(1.52)$ & $2.971(0.61)$ \\
\hline Age & $0.768(0.33)$ & $-0.946(-0.93)$ & $-2.391^{*}(-1.82)$ & $-5.007^{* *}(-2.37)$ & $-1.463(-0.72)$ & $-1.928(-1.33)$ \\
\hline Firm & Yes & Yes & Yes & Yes & Yes & Yes \\
\hline Year & Yes & Yes & Yes & Yes & Yes & Yes \\
\hline LR Chi ${ }^{2}$ & 139.64 & 69.12 & 177.15 & 39.70 & 122.19 & 86.18 \\
\hline OBS & 153 & 256 & 336 & 73 & 130 & 279 \\
\hline
\end{tabular}

$Z$-Statistics reported in parentheses. ${ }^{*} p<0.1,{ }^{* *} p<0.05$, and ${ }^{* * *} p<0.01$.

incentives to carry out innovation activities. Sometimes they cannot get rewarded from the innovation but have to undertake the costs [47].

PV enterprises have been granted large amounts of subsidies through the newly added investment in PV system and supporting facilities since 2009. However, substantial subsidies may induce PV enterprises to expand production to benefit from economies of scale and shift resources from risky $\mathrm{R} \& \mathrm{D}$ activities towards exploiting existing mature technologies. To absorb the rapid growth of PV power generation, these subsidies were terminated in 2013 and then switched to feed-in tariffs or based on the kilowatt hours of power generation. According to the policy orientations, Golden Solar Demonstration Project is an investment-orientation policy, which is subsidized based on the amount of investment of PV enterprises in 2010-2013. Feed-in tariff (FIT) is a demand-side government policy, which is designed to cope with excess capacity and stimulate enterprises to improve competitiveness in the PV market through R\&D efforts after 2014 [59]. The different policy orientations may influence the impact of R\&D subsidies and non-R\&D subsidies on the innovation of PV enterprises. Thus, we selected research samples during the period of 2010 to 2013 in the group under investment orientation and those during the period of 2014 to 2019 in the group under demand orientation.

In Table 6, the results of the group under investment orientation are provided in column (11), and the results of the group under demand orientation are provided in column (12). The coefficients of RDSub and NRDSub are insignificant in column (11), but the coefficient of RDSub is positively significant in column (12). This implies that R\&D subsidies granted under demand orientation have a positive impact on the innovation in PV enterprises. A large amount of GSs was provided through "Golden Solar Demonstration Project in China" to stimulate the production capacity of PV enterprises since 2009, and resources in PV enterprises may be shifted from risky R\&D activities towards expanding installation. After 2013, the project was terminated but switched to promote the generation capacity of PV electricity through FITs or based on the kilowatt hours of generated power. When PV power price subsidies were reduced gradually, PV enterprises have to enhance the marginal returns in the market through technological progress [60], which may encourage PV enterprises to pay more efforts into $R \& D$ activities and obtain a competitive advantage in the market.

\section{Conclusions and Discussion}

As a rapidly developing economy, China has attracted a lot of global attention $[61,62]$. In recent years, large amounts of GSs have been subsidized to PV enterprises in China. There is an arising controversy about whether these subsidies have promoted the R\&D efforts of PV enterprises. With samples of Chinese listed PV enterprises from 2010 to 2019, this study investigates the impact of R\&D subsidies on the innovation in PV enterprises and finds some conclusions as follows.

First, R\&D subsidies exert a significant and positive influence on the innovation in PV enterprises. Since the environmental externalities and knowledge spillover cannot be fully compensated by the market price, innovation in PV enterprises may encounter "double externality problem" $[8,9]$. Thus, R\&D subsidies are critical for PV enterprises' innovation. On the one hand, $R \& D$ subsidies can reduce the negative impact of external spillover of innovation achievements on enterprises' innovation motivation, and on the other hand, they can broaden enterprises' financing channels by releasing positive signals. This conclusion confirms the effectiveness of government $\mathrm{R} \& \mathrm{D}$ subsidy policy, which is of great significance to the promotion of sustainable innovation in PV industry.

Second, in heterogeneity analysis, we find R\&D subsidies and non-R\&D subsidies have significant and positive impacts on the innovation in SMEs and PV enterprises without state-owned shares. Compared to SMEs, large PV enterprises can undertake $\mathrm{R} \& \mathrm{D}$ risks with stable internally generated funds and average the R\&D costs through a large volume of production and sales. Therefore, large PV enterprises are less enthusiastic about spending $R \& D$ subsidies to accelerate innovation than SMEs. In China, since stateowned PV enterprises have a greater need to serve government objectives to secure legitimacy, PV enterprises with a higher proportion of state-owned shares are usually less 
likely to conduct risky innovation activities than private ones. This suggests that the government should consider the size and ownership of enterprises and allocate resources reasonably when granting $\mathrm{R} \& \mathrm{D}$ subsidies to $\mathrm{PV}$ enterprises.

Third, considering the policy orientation, R\&D subsidies granted under demand orientation have a significant and positive impact on the innovation in PV enterprises. Generous GSs from the supply side may create incentives for PV enterprises to capture scale economies by using existing mature technologies and shift resources from risky R\&D activities towards expanding installation [9]. To foster advanced technologies in PV industry, demand-side R\&D subsidies should be granted at proper rates $[59,63]$.

Thus, this article gives corresponding policy recommendations. Firstly, the government should attach importance to the positive signaling role of R\&D subsidies policy and increase the amount of R\&D subsidies to PV industry. Secondly, the government should continue to optimize the R\&D subsidies evaluation mechanism, comprehensively consider the size and ownership attributes of enterprises, and implement differentiated subsidy policies. Thirdly, to foster advanced technologies, larger PV enterprises should be guided to make breakthroughs in key technologies. Since state-owned PV enterprises have a greater need to serve government objectives to secure legitimacy, the government should also emphasize the strategic priority of innovation rather than production explosion to stimulate the R\&D efforts of state-owned PV enterprises. Finally, the government should attach importance to the leading position of the market in the allocation of resources. When implementing the subsidy policies, the government should consider the market supply and demand and pay more attention to the $\mathrm{R} \& \mathrm{D}$ subsidy from the demand side.

There are two deficiencies in this article. First, at the current stage, non-listed PV enterprises have no explicit government regulations to disclose enterprises' financial data and R\&D subsidy data, resulting in the lack of sample size. Second, this article only analyzes the role and heterogeneous impact of R\&D subsidies on the innovation of photovoltaic enterprises and confirms the effectiveness of government $\mathrm{R} \& \mathrm{D}$ subsidy policy. In the future, we should further explore the mechanisms by which $R \& D$ subsidies affect innovation of PV enterprises and the signal effect of $\mathrm{R} \& \mathrm{D}$ subsidies on attracting commercial banks, venture capital, and other external investors.

\section{Data Availability}

The datasets used or analyzed during the current study are available from the corresponding author on reasonable request.

\section{Conflicts of Interest}

The authors declare that they have no conflicts of interest.

\section{Authors' Contributions}

$\mathrm{CJ}$ and QZH were responsible for conceptualization and review and editing. DL and LW curated the data. CJ contributed to formal analysis. QZH was responsible for original draft preparation.

\section{Acknowledgments}

This research was funded by the National Social Science Foundation of China (20BGL046).

\section{References}

[1] A. Masoud, "Renewable energy and water sustainability: lessons learnt from TUISR19," Environmental Science and Pollution Research, vol. 27, no. 26, pp. 32153-32156, 2020.

[2] E. R. Rene, T. Bhaskar, B. I. Sang et al., "Innovation in environmental bioprocess for sustainable development," Environmental Science and Pollution Research, vol. 27, no. 22, pp. 27169-27171, 2020.

[3] Y. Yang, P. Nie, H. Liu, and M. Shen, "On the welfare effects of subsidy game for renewable energy investment: toward a dynamic equilibrium model," Renewable Energy, vol. 121, pp. 420-428, 2017.

[4] D. Zhang, J. Wang, Y. Lin et al., "Present situation and future prospect of renewable energy in China," Renewable \& Sustainable Energy Reviews, vol. 76, no. 76, pp. 865-871, 2017.

[5] D. Krawczyk, M. Zukowski, and A. Rodero, "Efficiency of a solar collector system for the public building depending on its location," Environmental Science and Pollution Research, vol. 27, no. 1, pp. 101-110, 2020.

[6] Y. Xiong and X. Yang, "Government subsidies for the Chinese photovoltaic industry," Energy Policy, vol. 99, pp. 111-119, 2016.

[7] National Energy Administration (2017), http://www.nea.gov. $\mathrm{cn} / 2018-01 / 24 / \mathrm{c} 136920159 . \mathrm{htm}$.

[8] L. Ardito, A. M. Petruzzelli, and C. Ghisetti, "The impact of public research on the technological development of industry in the green energy field," Technological Forecasting and Social Change, vol. 144, pp. 25-35, 2019.

[9] J. Hoppmann, M. Peters, M. Schneider et al., "The two faces of market support-how deployment policies affect technological exploration and exploitation in the solar photovoltaic industry," Research Policy, vol. 42, no. 4, pp. 989-1003, 2013.

[10] C. Jiang, Y. Zhang, Q. Zhao, and C. Wu, "The impact of purchase subsidy on enterprises' R\&D efforts: evidence from China's new energy vehicle industry," Sustainability, vol. 12, no. 3, p. 1105, 2020.

[11] Q. Wang, J. Qu, B. Wang, P. Wang, and T. Yang, "Green technology innovation development in China in 1990-2015," Science of The Total Environment, vol. 696, Article ID 134008, 2019.

[12] B. Sung, "Do government subsidies promote firm-level innovation? Evidence from the Korean renewable energy technology industry," Energy Policy, vol. 132, pp. 1333-1344, 2019.

[13] E. Karakaya, "Finite element method for forecasting the diffusion of photovoltaic systems: why and how?" Applied Energy, vol. 163, pp. 464-475, 2016.

[14] D. Bhattarai, E. Somanathan, and M. Nepal, "Are renewable energy subsidies in Nepal reaching the poor?" Energy for Sustainable Development, vol. 43, pp. 114-122, 2018.

[15] Y. Nomaguchi, H. Tanaka, A. Sakakibara et al., "Integrated planning of low-voltage power grids and subsidies toward a distributed generation system-case study of the diffusion of photovoltaic in a Japanese dormitory town," Energy, vol. 140, pp. 779-793, 2017. 
[16] N. Ameli, M. Pisu, and D. M. Kammen, "Can the US keep the PACE? A natural experiment in accelerating the growth of solar electricity," Applied Energy, vol. 191, pp. 163-169, 2017.

[17] S. Hagerman, P. Jaramillo, and M. G. Morgan, "Is rooftop solar PV at socket parity without subsidies?" Energy Policy, vol. 89, pp. 84-94, 2016.

[18] Y. Zhang, J. Song, and S. Hamori, "Impact of subsidy policies on diffusion of photovoltaic power generation," Energy Policy, vol. 39, no. 4, pp. 1958-1964, 2011.

[19] K. Torani, G. Rausser, and D. Zilberman, "Innovation subsidies versus consumer subsidies: a real options analysis of solar energy," Energy Policy, vol. 92, pp. 255-269, 2016.

[20] G. Wang, Q. Zhang, Y. Li, and H. Li, "Policy simulation for promoting residential PV considering anecdotal information exchanges based on social network modeling," Applied Energy, vol. 223, pp. 1-10, 2018.

[21] D. Guo, Y. Guo, and K. Jiang, "Government-subsidized R\&D and firm innovation: evidence from China," Research Policy, vol. 45, no. 6, pp. 1129-1144, 2016.

[22] D. Zhang, Q. Chai, X. Zhang et al., "Economical assessment of large-scale photovoltaic power development in China," Energy, vol. 40, no. 1, pp. 370-375, 2012.

[23] L. Xu, Q. Zhang, K. Wang, and X. Shi, "Subsidies, loans, and companies' performance: evidence from China's photovoltaic industry," Applied Energy, vol. 260, Article ID 114280, 2020.

[24] J. Yuan, S. Sun, W. Zhang et al., "The economy of distributed PV in China," Energy, vol. 78, pp. 939-949, 2014.

[25] D. Mayr, J. Schmidt, and E. Schmid, "The potentials of a reverse auction in allocating subsidies for cost-effective rooftop photovoltaic system deployment," Energy Policy, vol. 69, pp. 555-565, 2014.

[26] I. Zelenika-Zovko and J. M. Pearce, "Diverting indirect subsidies from the nuclear industry to the photovoltaic industry: energy and financial returns," Energy Policy, vol. 39, no. 5, pp. 2626-2632, 2011.

[27] E. L. Olson, "Green innovation value chain analysis of PV solar power," Journal of Cleaner Production, vol. 64, pp. 73$80,2014$.

[28] N. M. Koseoglu, J. C. J. M. van den Bergh, and J. S. Lacerda, "Allocating subsidies to R\&D or to market applications of renewable energy? Balance and geographical relevance," Energy for Sustainable Development, vol. 17, no. 5, pp. 536$545,2013$.

[29] F. Nicolli and F. Vona, "Heterogeneous policies, heterogeneous technologies: the case of renewable energy," Energy Economics, vol. 56, pp. 190-204, 2016.

[30] N. Johnstone, I. Haščič, and D. Popp, "Renewable energy policies and technological innovation: evidence based on patent counts," Environmental and Resource Economics, vol. 45, no. 1, pp. 133-155, 2010.

[31] W. T. Tsai, "Feed-in tariff promotion and innovative measures for renewable electricity: Taiwan case analysis," Renewable and Sustainable Energy Reviews, vol. 40, pp. 1126-1132, 2014.

[32] R. Bronzini and P. Piselli, "The impact of R\&D subsidies on firm innovation," Reserach Policy, vol. 45, no. 2, pp. 442-457, 2016.

[33] M. Lucy and M. David, "Testing a model of UK growth: a role for R\&D subsidies," Economic Modelling, vol. 82, pp. 152-167, 2019.

[34] Y. Gao, Y. Hu, X. Liu, and H. Zhang, "Can public R\&D subsidy facilitate firms' exploratory innovation? The heterogeneous effects between central and local subsidy programs," Research Policy, vol. 50, no. 4, Article ID 104221, 2021.
[35] T. Wu, S. W. Yang, and J. J. Tan, "Impacts of government R\&D subsidies on venture capital and renewable energy investment-an empirical study in China," Resources Policy, vol. 68, Article ID 101715, 2020.

[36] Q. Li, M. Wang, and L. Xiangli, "Do government subsidies promote new-energy firms' innovation? Evidence from dynamic and threshold models," Journal of Cleaner Production, vol. 286, Article ID 124992, 2021.

[37] B. Sun, R. Ao, B. Peng, and S. Liu, "Pay disparities within top management teams, marketization and firms' innovation: evidence from China," Journal of the Asia Pacific Economy, vol. 1, pp. 1-21, 2021.

[38] C. Dimos and G. Pugh, "The effectiveness of R\&D subsidies: a meta-regression analysis of the evaluation literature," Research Policy, vol. 45, no. 4, pp. 797-815, 2016.

[39] R. Kleer, "Government R\&D subsidies as a signal for private investors," Research Policy, vol. 39, no. 10, pp. 1361-1374, 2010.

[40] M. G. Andrade Rojas, E. R. R. Solis, and J. J. Zhu, "Innovation and network multiplexity: R\&D and the concurrent effects of two collaboration networks in an emerging economy," Research Policy, vol. 47, no. 6, pp. 1111-1124, 2018.

[41] T. Kang, C. Baek, and J.-D. Lee, “The persistency and volatility of the firm R\&D investment: revisited from the perspective of technological capability," Research Policy, vol. 46, no. 9, pp. 1570-1579, 2017.

[42] M. P. Feldman and M. R. Kelley, "The ex ante assessment of knowledge spillovers: government R\&D policy, economic incentives and private firm behavior," Research Policy, vol. 35, no. 10 , pp. 1509-1521, 2006.

[43] M. Marino, S. Lhuillery, P. Parrotta, and D. Sala, "Additionality or crowding-out? An overall evaluation of public R\&D subsidy on private R\&D expenditure," Research Policy, vol. 45, no. 9, pp. 1715-1730, 2016.

[44] M. Meuleman and W. De Maeseneire, "Do R\&D subsidies affect SMEs' access to external financing?" Research Policy, vol. 41, no. 3, pp. 580-591, 2012.

[45] W. M. Cohen and S. Klepper, "The anatomy of industry R\&D intensity distributions," The American Economic Review, vol. 82, no. 4, pp. 773-799, 1992.

[46] Y. Ma, X. Zhang, and Y. Sun, "Can environmental regulations stimulate the enterprises' R\&D efforts? An empirical analysis based on the data of thermal power plants," Science Research Management, vol. 39, no. 2, pp. 66-74, 2018.

[47] Z. Rong, X. Wu, and P. Boeing, "The effect of institutional ownership on firm innovation: evidence from Chinese listed firms," Research Policy, vol. 46, no. 9, pp. 1533-1551, 2017.

[48] Å. Cappelen, A. Raknerud, and M. Rybalka, "The effects of $\mathrm{R} \& \mathrm{D}$ tax credits on patenting and innovations," Reserach Policy, vol. 41, no. 2, pp. 334-345, 2012.

[49] C. Köhler, W. Sofka, and C. Grimpe, "Selective search, sectoral patterns, and the impact on product innovation performance," Reserach Policy, vol. 41, no. 8, pp. 1344-1356, 2012.

[50] J. Y. Lo, R. Nag, L. Xu et al., "Organizational innovation efforts in multiple emerging market categories: exploring the interplay of opportunity, ambiguity, and socio-cognitive contexts," Reserach Policy, vol. 49, no. 3, Article ID 103911, 2020.

[51] P. Boeing, E. Mueller, and P. Sandner, "China's R\&D explosion-analyzing productivity effects across ownership types and over time," Research Policy, vol. 45, no. 1, pp. 159-176, 2016.

[52] C. Jiang, Y. Zhang, M. Bu, and W. Liu, "The effectiveness of government subsidies on manufacturing innovation: evidence 
from the new energy vehicle industry in China," Sustainability, vol. 10, p. 1692, 2018.

[53] C. Böhringer, A. Cuntz, D. Harhoff, and E. Asane-Otoo, "The impact of the German feed-in tariff scheme on innovation: evidence based on patent filings in renewable energy technologies," Energy Economics, vol. 67, pp. 545-553, 2017.

[54] X. Zhang, Y. Wang, and B. Shi, "De facto exchange rate regime, firm productivity and export product quality," Word Economy, vol. 1, pp. 170-192, 2020.

[55] X. Liang and A. Liu, "The evolution of government sponsored collaboration network and its impact on innovation: a bibliometric analysis in the Chinese solar sector," Reserach Policy, vol. 47, no. 9, pp. 1295-1308, 2018.

[56] A. J. Revilla and Z. Fernández, "The relation between firm size and R\&D productivity in different technological regimes," Technovation, vol. 32, no. 11, pp. 609-623, 2012.

[57] G. N. Stock, N. P. Greis, and W. A. Fischer, "Firm size and dynamic technological innovation," Technovation, vol. 22, no. 9, pp. 537-549, 2002.

[58] F. Yu, Y. Guo, K. Le-Nguyen, S. J. Barnes, and W. Zhang, "The impact of government subsidies and enterprises' R\&D investment: a panel data study from renewable energy in China," Energy Policy, vol. 89, pp. 106-113, 2016.

[59] D. Zhou, Z. Chong, and Q. Wang, "What is the future policy for photovoltaic power applications in China? Lessons from the past," Resources Policy, vol. 65, Article ID 101575, 2020.

[60] P. Sun and P. Nie, "A comparative study of feed-in tariff and renewable portfolio standard policy in renewable energy industry," Renewable Energy, vol. 74, pp. 255-262, 2015.

[61] W. Liu, L. Tang, M. Gu, and G. Hu, "Feature report on China: a bibliometric analysis of China-related articles," Scientometrics, vol. 102, no. 1, pp. 503-517, 2015.

[62] J. Zhu and W. Liu, "Comparing like with like: China ranks first in SCI-indexed research articles since 2018," Scientometrics, vol. 124, no. 2, pp. 1691-1700, 2020.

[63] B. Lin and R. Luan, "Are government subsidies effective in improving innovation efficiency? Based on the research of China's wind power industry," Science of The Total Environment, vol. 710, Article ID 136339, 2020. 